\title{
AN ASSESSMENT OF DEMOCRACY AND MORAL DEVELOPMENT IN AFRICA
}

\author{
ADEFARASIN, V.O. \\ Olabisi Onabanjo University, Ago-Iwoye, Nigeria
}

(C) The Author(s) 2021

\section{ABSTRACT}

This paper argues that democracy has an intrinsic value that has given it a wide acceptance all over the world. Democracy has been conceived as a fundamental creed in order to effectively oppose and overthrow the established order of the Monarchical and Aristocratic rule. But these values are no longer in place due to moral laxity in the society today. The paper discusses meaning and definitions of democracy, fundamental principles of democracy, meaning and definitions of development, theories of development, and dimensions of development and features of development. This paper posits further that in today's society, morality is a necessary factor in the actualization of intrinsic values of democracy. The good of democracy may not be fully actualized where the citizens are not morally developed. It is on this basis, that the citizens should adhere strictly to democratic rules, ethos and principles and these can only be achieved when citizens are morally developed.

\section{(C) 2021.All rights reserved.}

\section{ARTICLE HISTORY}

Received: $28 / 11 / 2020$

Accepted:10/03/2021

Published online:30/04/2021

\section{KEYWORDS}

Assessment, Democracy, Moral Development, Society, Citizens 


\section{Introduction}

Without mincing words, democracy has become a global hype and the democratic wind of change has swept like a hurricane or a virus across the length and the breath of Africa. Not less than 70 percent of states in Africa have embraced democracy. This situation is not unconnected with the common view that democracy is the only viable and sustainable mode of organizing society for development. It is patronized and widely acclaimed as the political messiah, for many of the seeming by unending socioeconomic and political problems facing humanity. The underlying belief is that the enthronement and sustenance of democracy (mostly in Africa) will solve virtually all problems confronting her (Africa) thereby leading to her development.

In the same vein, many countries in the world use the appellation, democratic society in order to signify to the other states that they are democratic. In a UNESCO survey carried out in 1962, practically every country in the world claimed that it was a democratic state (Irele 1998:83). By all known standards and with all intents and purposes, democracy is still the best form of government. Democracy, with all its defects, implies a recognition of the duties of government and the rights of the people. It postulates a measure of personal freedom and equal consideration for all classes. Democracy paves way for development because those elected are responsible and accountable to the people, though in an ideal society.. It is a government founded on the people's will. The people determine who gets what, when and how it implies recognizing the people as the source of all political power and authority. The people's will is usually expressed by way of election.

At this juncture, it is expedient to declare that for democracy to strive, all necessary elements for its substance must exist which include, but not limited to: a general acceptance of electoral and political party arrangements within which diverse groups' interest are represented, the formal constitutional manifestations of these democratic practices include representatives bodies such as parliament, elected executives and a virile judiciary. Despite this, people do not allow democracy to thrive and thereby depriving people of reaping "the dividends of democracy". 
One fundamental factor responsible for this is the complete absence of moral development. It is a pre-requisite and a condition-sine-qua-non for democratic order in the society. This precedes all dimensions of development vis-a-vis democracy.

\section{Meaning and Definitions of Democracy}

The term democracy means several things to different persons. The root word for democracy is the Latin word "democratia" meaning rule by the people (Dukor, 2003:202). According to Irele (1998:3) the word comes from two Greek words "demos" and kratei which mean "the people rule". Now, having given the etymological derivation of democracy, we shall now give its definitions. What then is democracy? It must be noted from the outset, that as a concept, it has been given different interpretations by social and political thinkers as well as the ordinary layman. Hence, we do not have a definition that satisfies everyone. However, the most and often quoted definition is the one given by Abraham Lincoln that "it is a government of the people, by the people and for the people" (Ibid: 84). It can also be defined as "the institutional arrangement for arriving at political decisions in which individuals acquire the power to decide by means of a competitive struggle for the people's vote" (Ibid:85)

According to Appadorai, (1968: 137) democracy may be described as a system of government under which the people exercise the governing power either directly or through representatives periodically elected by themselves. This means that a state may, in political science, be termed a democracy, if it provides institutions for the expression and, in the last analysis, the supremacy of the popular will on basic questions of social direction and policy. Democracy, for Ramsaswamy (2015:388), means "government by consent that can be elicited through elections that register voters' decision". On his part, Heywood (2007:72) maintains that the origins of the term democracy can be traced back to Ancient Greece. Like other words ending in "cracy" (for example, autocracy, aristocracy and bureaucracy) democracy is derived from the Greek word Kratos, meaning, power or rule. Democracy thus means 'rule by the demos' referring to the 'the people' 


\section{Fundamental Principles or Ideals of Democracy}

Let it be stated that any democratic form of government should have certain ideals that are important for it to be called a democratic state. For the purpose of clarity therefore, these shall be marshalled here. Freedom, equality, accountability to people, right to vote and be voted for among others. Odimegwu (2006:60) adds to these ideals by saying that, for a state to be democratic,there should be a free, fair and uninfluenced election carried out by an Independent Electoral body.

Again, it must be borne in mind that the ideals of democracy are taken as necessary preconditions for democracy. Therefore, the notion of equality contains five separate ideas that are used in varying degrees or combinations by democratic theorists. These are: political equality, equality before the law, equality of opportunity, economic equality, and social equality.

Other important principle of democratic system is that the government is accountable to the people. The core of the democratic process is that the people can call their representatives to account for their policies. This is carried out through periodic elections which are open and, above all, competitive.

1. Equality of Men: The most fundamental tenet of democracy, and that which distinguishes it from all other political creeds, is the concept of equality of men. All human beings are born equal.

2. Individual Rights: Democracy considers the dignity and worthy of individual sacred and inviolable.

3. Majority Rule, Minority Rights: The central principles of government based on democracy, however, are rule by consultation and consent of the vast majority of the people, and the recognition of the basic rights and the freedom to dissent and hold contrary views of the minority. (Ogunmodede, 1985:148-151)

\section{Meaning and Definitions of Development}

The World currently revolves around development. This is because the need for development occupies a primary place in the lives of individuals, groups, nations and states. The desire is always for a people to move closer to development. Those who are 
farthest from it wish they were closer and consistently strive to be closer to it, while those who are close to it wish there were nothing separating them from development. Perhaps, the most intriguing aspect of the situation has to do with those by whom we sometimes measure development. They are involved at another level, in the race for further development and this involves discovering new frontiers of development and the process increases, as much as possible, the developmental gap between themselves and others. In this situation, the term 'Development' turns out to be a very vague term. This is because in our ever-changing World, there are no archetypes of development. Changes that are considered to be developmental today, may be considered primitive tomorrow. Also, what is considered to be development in one place, may be seen to be an index of retrogression in another. This makes it difficult to articulate a definite concept of development.

The problem of development is a nagging and recurrent issue. Like an ailment, it has received several diagnoses, prognoses and treatment. Yet, the disease persists. It does not seem that it can be totally cured. Some countries seem to have achieved selfsustaining growth. Some are striving for it, while others are not only finding it difficult to attain, but also seem to be stagnant especially, economically. Citizens of some countries participate in the determination of their environment, whereas, this is not the case in others. Similarly, peoples of certain nations have the opportunity to choose and use their resources to maximum capacity, while others do not seem to be so privileged. Usually, developed countries, particularly advanced capitalist ones, initiate and execute ethnocentric policies with little or no regard for the interests of underdeveloped one. The following questions are pertinent: What is responsible for these states of affairs? Why are some countries developed while others are underdeveloped?

According to Henry McGurk, (1975:28) "development implies not only a change in time, but also change which has direction; development frequently implies advancement or improvement over some more primitive status". Harris Dale defines development as "a sequence of continuous changes eventuating in some outcome" (1957:15). What this adds to the McGurk's position is that developmental change is not isolated incident. It must be part of a process emanating from the past and gradually building up to the present and the future. Harris also adds that it has as its essential components "the notions of a system possessing a definite structure and a definite set of 
pre-existing capacities; and the notion of a system yielding permanent but novel increment not only in structure but in its modes of operation as well" (Ibid, 17).

Besides, the term development is borrowed from biology. It describes a process through which the potentials of an object or organism are realized, until it reaches its natural, complete, full-fledged form”. (Oladipo \& Olorunyomi, 1999:13). Development can also be defined as "growth plus change. Change; in turn is social and cultural as well as economic and qualitative as well as quantitative. The key concept must be improved quality of people's life". Development is "the act of developing into a form of something". To develop is to expand or realize the potentials of bringing gradually into a fuller, greater, or better state" (Williams, 1980:360). Development, here is progressive with the potentiality to achieve fuller realization. Development refers "to the progressive changes that take place in the growing organism as he/she advances towards maturity" (Amao Kehinde, 2000:17). Though, this definition is biological, the relevant point in it is that development has to do with progress, changes and maturity. Obasanjo and Mabogunje (1991:3) said development could be defined as "a change or a transformation into a better state". After tracing the evolution of the idea of development, Obasanjo and Mabogunje said that "development now emphasizes people as the object of attention. It is no longer just about growth in the volume of goods and commodity. It is now to be thought of as a process concerned with people's capacity in a defined and over a defined period to manage and induce positive change". Rita Abrahmsen (2000:15) is of the view that the idea of development entered into epistemology immediately after the Second World War in 1949 when President Harry Truman (0f the United States), in his speech introduced the term, 'underdeveloped areas' and marks the launch of the global effort to develop the World and eradicate poverty".

In his own conceptualization of development, Baster Nancy says that 'the questions to ask about a country's development are: What has been happening to poverty, unemployment, inequality? If all these three have become less severe, then beyond doubt, this has been a period of development for the country's concerned" (1972:22). For Frances Stewart (1977:19-22) technology is the backbone of development without it, no country can be said to have developed. 
Again, in the existential ontology of Martin Heidegger, development can be understood as the achievement of authentic nationhood; and underdevelopment, the inability of a nation to overcome confidence-crisis. Any nation that thus refuses or is incapable of building on its factical givens cannot be a sovereign nation where a sovereign nation is understood to be a nation that is free from external determination and control. Any externally determined nation can hardly acquire stature and maturity. A nation without a sound ideological framework of its own to guide social action, a nation that goes about copying every available piece of ideology is vulnerable, and like an edifice without foundation, such a nation easily falls prey to the windstorm of imperialism. Such a nation is not genuine and is therefore lost in the in-authentic 'they World' where failure and misfortune are explained away in terms of sabotage. A nation that keeps another in the hope that one of them would provide a permanent solution to its social and economic problems is an inauthentic nation. The mode of being of such a nation is fraudulent and counterfeit. In the same way, a nation that refuses or is unable to act decisively, nation that cannot reject external control or is unable to throw off the yoke of alien manipulation because the stakes are too high is gripped by confidence crisis and such a nation dwells in the domain of in authenticity (Unah, 1996:118-119).

In Hegelian idealism, development is not only in terms of ideas, it is also, essentially dialectical. It is the inescapable consciousness of the mind for progress even in the face of opposition. Development for Hegel is therefore inevitable. It is craving, the desire of the mind to reach for the highest level of spiritual advancement that culminates in the Absolute idea, the overall governor of the World, of existence and of the being of man (Findlay, 1971:1). According to Hegel, development is fundamentally mental; it is prima facie, an idea before it can be concretized. Ake Claude, (2001:32) argues that development can only be related to and driven by social will in the context of democracy. It is only in this context that the people can be a means and the end of development." Put differently, development is best initiated internally and nurtured by the people in need of a particular development, otherwise, there can never be development. Development can also be described as "the mind leading to a complete mastery over nature in which can be the humanity of man is no longer subjugated to nature" (Balogun et al., 1988:178). Udoidem Iniobong (1992:25) maintains that development can be defined as "a process leading to the realization of full human and 
environmental potentials. If, therefore, in our thrust toward community development, the full human and environmental potentials are not realized, then, the community is yet to be developed". Also, Ogundowole, E.K. (2002:162) opines that "meaningful development is self-realization". This implies the use of the resources of geosphere, imagination and unprecedented ingenuity to achieve overall societal objectives. It entails the increasing expansion of what a purposeful self-realiancist mind, poised at full realization and recovery can do with simple objects of his immediate geographical and historical environment. Hence, it may be said that development is not so much a matter of what we have, but of what we do with what we have; how we do it and how well". He goes further to say that development, thus, is the desire and ability to use what is available to continuously improve the quality of life, liberate people from the hazardous power and influence of natural geophysical, socio-historical and World environment. In a nutshell, development must begin with the desire to improve lot through our own efforts. According to Ogundowole, development then, is like ambition, it cannot be received by people from another people. Development requires the ability to learn how to improve one's own well being. It involves the ability to act and while acting to apply knowledge thoroughly in all spheres of activity. He goes further by stressing that development as a process and as a concept is broader and is multi-dimensional. It may mean a mechanical motion, the spatial displacement of objects. It may mean a forward, backward, sideways, upward and/or downward movement. It may mean rectilinear, rotatory, oscillating, etc motion" (Ibid, 164). He goes on to say that for Frantz Fannon and Nkrumah, both hold that development means decolonization, and Nyerere who insists that development is liberation.

According to H. Miller, (1974:105) "a development is a temporal change having a beginning and end. It is unit of progress, a real unit of change. Secondly, it is a recognizable and describable process, one that recurs again and again at different times and places. And thirdly, it is a cumulative or directed process, one which points throughout its course to certain definable goal or terminus". On his part, Pearson, (1970:7) maintains that development is partly a process whereby a country achieves a reasonable self-sustaining growth which facilitates and enhances industrial and technological progress in the interest of its people". Some of the pre requisites for this type of development according to him are: the application of modern science and 
technology, reasonable political stability, and efficient administration and organization. He affirms that development takes place when the people participate in the determination of their environment, and are allowed to choose and use their resources to the maximum capacity.

Development is also seen as a growth from a certain stage of life conceived to be primitive to another stage conceived to be modern. Development involves "a series of interactions (social relations) and other factors which in Africa would include values, way of life, beliefs, traditions as well as good governance, which allows human participation at all levels of decision making" (Dukor, 2003:97). Now, of all these plethora of definitions of development, I will like to pitch my tent with one of the definitions which says that development is the act of developing into a form of something. In other words, to develop is to expand or realize the potentials of bringing gradually into a fuller, greater, or better state. One of the reasons for this is that development should not be a stagnant thing; it should go with changes; it should equally go with new dimensions, innovations, advancement and new ideas. It should move from one stage into another that will lead to new discoveries.

\section{Dimensions of Development}

Development is a many-sided process. It is not a unitary or homogeneous concept; it is multidimensional, for, it appears in all aspects of human endeavour. The term development stands out as primary icon in various aspects of human theatre. This idea of development as being multidimensional is further reinforced in that "development has economic, social, political, cultural, educational, technological, human and personal dimensions" (Fadahunsi, 1998:157).

\section{Human Development}

If any development drive is to be meaningful, it must be people oriented. Development efforts that are not targeted at the well-being of the people cannot be said to be meaningful. In the opinion of Omoregbe Joseph, (1999:197)"the primary aspect of development in any country is the development of human dimension. In other words, development of human personality is primarily the development of a nation. All other 
aspects of development are subordinate and instrumental to human development". Some scholars have also expressed their views on human development. Ann Babu (1981:157) maintains that "hitherto untapped human ingenuity and material resources will come into full play, crushing all obstacles, natural or man-made on the way". A development according to Iroegbu Pantaleon (1996:148) is people oriented, human centered and citizens anchored, when the people are accorded primacy as the subject and object of attention in development effort." In other words, human development is an existence when there are continuous opportunities given and opens to man in order to improve his skills and abilities.

In the same vein, Julius, Nyerere (1973:12) maintains that development is nothing but human development. That is, it is a process whose primary goal is human well-being, both its material and moral dimensions. He stresses further by saying that "roads, building, the increase of the crop output, and other things of this nature are not development, they are tools of development. A new road extends a man's freedom if he travels upon it. An increase in the number of school buildings is development only if those buildings can be and are being used, to develop the minds and the understanding of the people. Development, which is not development of the people, may be of interest of historians in the years 3000. It is irrelevant to future that is being created. From this, it can be deduced that the enhancement of the well being of the people is the primary goal of any development.

\section{Economic Development}

Economic development is characterized with improvement in quality of life coupled with the liberation from the yoke of in productivity and retrogressiveness as well as static economic situation. A country is said to be economically developed, when the country is independently of outside control or direction, organizes the exploitation and development of its total resources, for the benefits of its entire people under a system in which the forces of supply and demand and marginal utility are controlled for the common good (Awolowo, 1968:2). What this boils down to is that the extent to which a country maximizes the available resources determines the strength of her economy. 


\section{Educational Development}

Educational development occupies another aspect of development worthy of discussion. And for there to be human development, the educational prerequisite for development must be fulfilled. The more a state is developed educationally, the more it is susceptible to an all-enhancing development. But what is educational development? It can be conceptualized as the emancipation of human beings from the cave of ignorance and illusion to the limelight of knowledge. It entails qualitative change and increase in literacy acquisition. Educational development emancipates people from the shackles of ignorance and improves their efficiency. It brightens the prosperity of the people and gives them a promising future. Hence, for a state striving towards qualitative and quantitative educational development, education should never be seen as a privilege, but as right of the entire citizens.

\section{Political Development}

To speak of political development, is to emphasize on "the qualitative increase in the level of the involvement of the people in the appointment of those with whom they trust their political destinies" (Onimode\& Synge, 1995:96-77). A political developed state implies an enhanced political participation based on the principle of accountability. That is, those who govern the state are accountable to those they govern. Political development in a state is determined by the degree and level of the democratization process in the state.

\section{Social Development}

Related to political development is social development. Though, many people have erroneously conceived social development to mean the provision of social services or the promotion of social welfare or independence from development aids. It involves the promotion of social reform human dignity and justice. Social development involves the respect for the views of others, acceptance of plurality of opinions as well as respect for the views of others. 


\section{Technological Development}

Technological development is the qualitative advancement recorded in the civilization of science and the technical application of its results. Technological development is the consistent increase in the application of the result of science for the improvement of the conditions of human life and control of man's environment for the suitability and comfort of man.

\section{Cultural Development}

While there exists a sort of relationship between cultural and social development [earlier discussed], there still exists a difference between them. Cultural development is the expanding and adaptive capacity of the society in satisfying the material and cultural needs of its members.

\section{Religious Development}

No development programme is completed without including within it a programme for religious upliftment and development. Religious development is the qualitative and quantitative increase in the purification of man's soul and accentuation towards the will of the supreme being- God. Religious development affords the citizens to foresee, identify, condemn and abstain from evil always wherever and whenever it surfaces in the society.

\section{Moral Development}

Morality is indispensable to development. The recent call for moral regeneration by scholars admits the quest for development, reinforces the importance of moral development. In fact, it can rightly be said that moral development is the basis for a well-rounded development. In other words, the prosperity of a society depends on the moral disposition of its members. Put differently, a state or society can never experience true development when the citizens are morally deficient. This position is akin to Omoregbe's conception of development when he opines that: moral development on the part of the citizens is therefore a condition sine qua non for the development of any 
nation. It must precede the economic development through modern technology. Neither science nor technology can develop a country, if its citizens are not morally developed" (Omoregbe, 1993:150). It is the moral development of the citizens that constitutes the development of the country.

\section{Theories of Development}

In addition to the meanings, definitions and dimensions of development earlier discussed, the idea of development will not be fully comprehended without a discussion of the theories of development. To this end, our concern here is to delve into the two prominent theories of development viz:, growth and modernization theories respectively. The foremost representative of the growth theory is W.A. Lewis, while that of modernization theory is W.W. Rostow. The two theories will now be fully explained.

\section{Development: The Growth Theory's Perspective}

W.A. Lewis, like other growth theorists, regards per capita income, gross domestic product, etc., as indicators of the level of development. He claims that three 'proximate causes' are essential to an understanding of growth and developmental issues. These are (1) the effort to economies (2) increase of knowledge and its application and (3) effort to increase the amount of capital (Lewis, 1963:11).

On the issue of capital, Lewis examines capital requirements, main sources of savings and process of investment. Any country which desires economic growth needs to increase its capital per head, among other things. He distinguishes between countries whose national income per head is not increasing and those with progressive nationals income per head. The former invest four or five percent of their national incomes or less whilst the latter invest twelve percent per annum or more. It is, however, possible for a ' 5 percent saver' to convert to '12 percent saver'. According to Lewis, this conversion is intelligible not merely in terms of increasing thrift, and of better use of savings but essentially in terms of immense increase in the share of profits in national income engineered by newly emergent class of profit making entrepreneurs. These entrepreneurs are "a small group of persons, private investors or public officials, who 
are disposing of large sums of capital, which employ large numbers of other people. (Lewis, 1963:265).

\section{Development: Modernization Theory's Perspective}

Rostow, among other modernization theorists, regard "the process of development as the business of the acquisition by the underdeveloped countries of the traits and characteristics of the developed countries". In other words, development is determined by the rate at which a country accumulates social, cultural, industrial or technological and other artifacts. This view tends to suggest that the development of countries such as Britain, Germany, etc. can be explained by the abundance by these artifacts. Another corollary of this conception of development is that countries which are underdeveloped remain so because they have not obtained enough of these artifacts. If they wish to develop, therefore, they need to acquire the traits and characteristics of the economically advanced countries. (Preston, 1982: 17)

In his theory, Rostow maintains that economic growth spans through five stages. They are the traditional society; the pre- conditions for take- off; the drive to maturity; and the age of high mass consumption. As he puts it:

Traditional societies, evolved within limited production functions... limitations of technology decreed a ceiling beyond which they could not penetrate. They did not lack incentives and innovations. ... (But) they lacked... the tools and the outlook towards the physical World of the post- Newtonian era. (Rostow, 1960:307)

\section{Features of Development}

These are some of the features of development:

$>$ Promotion of equality of the people.

$>$ Absence of exploitation.

$>$ Promotion of the dignity and respect for human beings.

$>$ Avoidance of discrimination on grounds of sex or colour.

$>$ Promotion of national independence at self reliance.

$>$ Subordination of economic growth to social growth. 
(Julius Nyerere, 1970:38 \& 50).

\section{Assessment of Democracy and Moral Development}

Having carefully explained what democracy and development entail, it is very important to do an assessment of these two concepts. From what has been said so far on these two concepts, it can be seen that there is a link, connection, symbiotic relationship and synergy between them. By the time we take these two concepts to philosophical realm, it will be seen that for democracy to thrive and survive, there should be room for moral development because, man's development is incomplete without morality. A person cannot live a happy life if he has no modicum and iota of morality in him. Also, no nation has ever attained greatness either by disparaging its conscience or by making a virtue and ideal out of immorality. And any great person or society that neglects morality heads for decadence and perdition (Ogunmodede, 1985:237-238)

At this juncture, it must be stressed that a very important aspect of the development of the human personality is moral development. Moral development and maturity on the part of the citizens of a country are pre-requisites for the development of that country. Indeed, moral development is the most important aspect of national development, for there can be no development of a country if its citizens are morally undeveloped and immature. Moral development on the part of the citizen is therefore a conditio-sine-qua-non for the development of any nation. It must precede the economic development through modern technology. Neither science nor technology can develop a country if its citizens are not morally developed. How can there be development in a country in which public funds are embezzled by those who control them and who are supposed to use them for development projects? How can there be development in a country in which self-interest is the dominant rule of action? Nor can the economy of any country develop if its citizens lack a moral responsibility to the society. How can there be development in a country in which bribery and corruption break down law and order? Also, Schweitzer (1961:76) opines that "the prosperity of a society depends on the moral disposition of its members"

It will be seen from the above synopsis that morality plays a vital role in our society. In fact, it is the soul of any society. Therefore, the thrust of my argument is that 
for democracy to succeed in our society, we should have flair for moral development. Momoh (1991:225) captures this when he avers that "the nation rarely fails in matter of expertise, skill and specialization." The area of monumental failure has always been the moral arena. In the same vein, Momoh (1994:68) argues that "the principle of moralism is an ideological antinode to the most of social predicaments confronting Nigeria, nay Africa." The core of moralism is the commitment to fairness, incorruptibility, social justice, patriotism, tolerance, unity and the development of the society. Moralism as a philosophical doctrine holds that "put the other before or alongside the self." What this boils down to is that honesty, service and concern for the interest of the other ought to be the basis and measure of all actions and policies. The objective of moralism, Momoh notes is that of "how much the action of an agent meets and satisfies the legitimate wants and demands of the other or how it minimizes the avoidable and necessary sufferings and pains of others" (Ibid:69)

In addition, it must be stated that for democracy to achieve its intended objectives, all the stakeholders, most especially the electoral officials must be morally upright. They are expected to be plain, unbiased and transparent. They must avoid corruption and corrupt practices like Ebola, Lassa fever, Aids and other deadly and contagious diseases. "The Punch" April 12, 2017: 1 reports that "our officials collected N3bn bribe to rig 2015 polls-INEC. Also, "The Nation" Tuesday, April 25, 2017:1 reports that "INEC Official arraigned for N112m bribe". A cursory look at this shows that these Independent National Electoral Commission officials were morally bankrupt and as a result we should not expect them to conduct free, fair, credible and acceptable election. They are by all known standards, to be independent, corrupt free and impartial. What is missing here therefore is moral development. Anybody who wants to be involved in any election should be morally upright. The questions then arise: Will these people deliver? Can they perform? The answer is No. Little wonder why Africa, despite her huge resources, both human and material, is poor. Not only she is poor, she suffers from economic epileptic, political leprosy, educational dysentery, ethnic jingoism, religious fanatism, and bigotism, kidnapping, terrorism among other social maladies. The point or hub of my idea can be encapsulated in this aphorism "morality is a significant aspect of politics and as such one cannot divorce it from politics or else, the very essence of politics will be drained out" 


\section{Conclusion}

From what has been adumbrated above, it is obvious that there is a synergy between democracy and moral development and as such, for Africa to develop and enjoy the real dividends of democracy, concerted efforts must be made to give room for moral development. Any society that throws away morality will go into a complete state of extinction. The culture of moralism must be embraced. Morality should be brought back to governance so that Africa can truly develop and join the comity of Nations.

\section{Disclosure statement}

No potential conflict of interest was reported by the author.

\section{Contact Information.}

Email address:adefarasinvo@yahoo.com adefarasinvo@gmail.com 


\section{References and notes:}

Abrahamsen, Rita (2000), Disciplining Democracy: Development Discourse and Good Governance, London: Zed Books.

Ake, Claude (2001), Democracy and Development in Africa, Ibadan: Spectrum Books.

Amao, Kehinde (2000), A Course Text on Human Development and Learning, Lagos: Obaroh Ogbinaka

Appadorai A, (1968) The Substance of Politics, New York: Oxford University Press.

Awolowo, Obafemi (1968), The People's Republic, Ibadan: Oxford University Press.

Babu, A.M. (1981), African Socialism or Socialist Africa, Dar-Es-Salam: Tanzania Publishing House.

Balogun, K. et al (eds.) (1988), The Place of Religion in the Development of Nigeria, Ilorin: Amora Press Ltd.

Dukor, Maduabuchi (ed) (2003), Philosophy and Politics: Discourse on Values, Polities and Power in Africa, Lagos: Malthouse Press Ltd.

Fadahunsi, Ayo (ed.) (1998), Philosophy: An Anthology, Lagos: Ark Publishers.

Findlay, J.N. (1971), Hegel's Philosophy of Mind, Oxford: Clarendom.

Haris, Dale (ed.) (1996), The Concepts of Development, Minnesota: University of Minnesota Press.

Heywood, Andrew (2007), Politic, UK: Palgrave Foundations.

Irele, Dipo (1998), Introduction to Political Philosophy, Ibadan: Ibadan University Press.

Ireogbu, Pantaleon (1996), Communalism: Towards Justice in Africa, Owerri: International Press Ltd.

Lewis, W.A. (1963), The Theory of Economic Growth, London: George Allen \&Unwin Ltd.

McGurk, Henry (1975), Growing and Changing. London: Methuen \& Co.

Miller, Huck (1974), An Historical Introduction to Modern Philosophy, New York: McGraw-Hill, Inc.

Momoh, C.S (1991), Philosophy of a New Past and an Old Future, Auchi: African Philosophy Projects Publication.

Momoh, C.S (1994), The Funeral of Democracy in Nigeria, Lagos: African Philosophy Projects Publication.

Morris, Williams (ed) (1980), The American Heritage Dictionary of English Language, Boston: Houghton Miffin.

Nkrumah, Kwame.(1970), Consciencism, Philosophy and Ideology for Decolonization.London: Monthly Review Press.

Nyerere, Julius (1970), Ujamaa: Essays on Socialism, Dar-es-Salam: Oxford University Press.

Nyerere, Julius (1973), Man and Development, Dar-es-Salam: Oxford University Press.

Obasanjo, Olusegun\&MabogunjeAkin (1991), Elements of Development, Abeokuta: A4 Publications.

Odimegwu, Ike (ed)(2006),Philosophy and Africa, Akwa: Lumos Nig. Ltd.

Ogundowole, Kolawole (ed) (2002), "Philosophy and Logic", Lagos: Obaroh\&Ogbinaka Publishers Ltd.

Ogunmodede Francis Ishola, (1985), Chief Obafemi Awolowo’s Socio Political Philosophy. A Critical Interpretation, Ibadan: Intec Printers Limited.

Oladipo, Olusegun \& Olorunyomi Sola (eds) (1999), View Point. A Critical Review of Culture and Society, Ibadan: Hope Publications.

Omoregbe, Joseph (1990), Knowing Philosophy, Lagos: Joja Educational Research and Publishers Ltd.

Omoregbe, Joseph (1993), Ethics. A systematic and Historical Study, Lagos: Joja Educational Research and Publishing Ltd.

Onimode, \& Richard, Synge (eds) (1995 $\square$, Issues in African Development. Ibadan: Heinemann Educational Books.

Pearson, L.B. (1970), The Crisis of Development, London: Pall Mall Press Ltd.

Preston, P.W. (1982), Theories of Development, London: Routlegdge and Kegan Paul Ltd.

Ramaswamy, Sushila (2015),Political Theory: Ideas and Concepts, New Delhi, PHI Learning Private Ltd.

Rostow, W.W. (1960), The Process of Economic Growth, Oxford: Clarendon Press.

Russell, Bertrand (1998), Principles of Social Reconstruction, London: Routledge Books.

Schweitzer, A. (1961), Civilization and Ethics, London, Unwin Books.

Stewart, Frances (1977), Technology and Underdevelopment, London: Macmillan.

"The Nation", Tuesday, April 25, 2017.

Udoidem, Inilbong (1992), Values and National Development, Lagos: African Heritage.

Unah, Jim (1996), Heidegger's Existentialism: An Essay on Applied Ontology, Lagos: Panaf. 